\title{
A successful year for the journal of management control
}

\author{
Thomas W. Guenther
}

Published online: 6 September 2014

(C) Springer-Verlag Berlin Heidelberg 2014

The Journal of Management Control looks back on a very successful year with wonderful inspiring articles, great support by reviewers and by members of the editorial board and a fruitful interaction with outstanding authors all over the world. We are greatful for having this platform for research in management accounting and control.

In 2013, submissions to JoMaC came from 18 different countries all around the world and reviewers covered 12 different countries of origin. Our journal is now available in more than 7,000 institutions all around the world. Fulltext downloads are constantly growing year by year and went up in 2013 by $19 \%$ in relation to 2012 . Full-text article requests are coming from North America (8\%), Asia-Pacific (22\%), South America (3\%), Africa (1\%), Middle East (7\%), Germany (32\%) and other European countries (27\%). Thus, our authors can be sure that their work is presented to a large global and growing scientific community. Average turnaround time between reception of the submission and first decision was 75 days. This demonstrates our intention to publish on one hand high quality paper and to enable authors on the other hand to publish their work in due course. The final acceptance rate for submissions reviewed in 2013 was $25.7 \%$.

To honour the great input and effort our reviewers invest in guiding authors to further improvements of their papers, the editors also voted for JoMaC's Best Reviewer Award in 2013. This year the editors are proud to honour the forthcoming colleagues:

Best reviewer award 2013: Stefan Linder, Essec Business School Paris, France

Runners up are: Martin Hiebl, Johannes Kepler University, Linz, Austria

Klaus Derfuss, Fernuniversität Hagen, Germany

T. W. Guenther $(\bowtie)$

Journal of Management Control, Technische Universität Dresden, 01062 Dresden, Germany

e-mail: jomac@mailbox.tu-dresden.de 
The editors of JoMaC appreciate the great, continuous support of all three researchers which contributed very valuable and helpful remarks and recommendation to our authors.

In 2013, the following reviewers in alphabetical order devoted their precious time for reviews of papers submitted to JoMaC (reviews finished in 2013):

\begin{tabular}{|c|c|c|c|}
\hline Prof. Dr. & Marcus C. & Arnold & University of Berne, Switzerland \\
\hline Prof. & Daria & Battini & University of Pavia, Italy \\
\hline Prof. Dr. & Wolfgang & Berens & University of Münster, Germany \\
\hline Prof. Dr. & Hans-Joachim & Böcking & Goethe University Frankfurt, Germany \\
\hline Prof. Dr. & Nils & Boysen & Friedrich Schiller University Jena, Germany \\
\hline Prof. Dr. & Alexander & Brüggen & Maastricht University, The Netherlands \\
\hline Prof. Dr. & Rolf & Brühl & $\begin{array}{l}\text { ESCP Europe Wirtschaftshochschule Berlin, } \\
\text { Germany }\end{array}$ \\
\hline Prof. & Ariela & Caglio & Università Bocconi, Italy \\
\hline Dr. & Yuval & Cohen & The Open University of Israel, Israel \\
\hline Prof. & Alberto & Dell'Acqua & Università Bocconi, Italy \\
\hline Dr. & Klaus & Derfuß & FernUniversität Hagen, Germany \\
\hline Dr. & Simon & Emde & Friedrich Schiller University Jena, Germany \\
\hline Prof. Dr. & Jürgen & Ernstberger & Ruhr-Universität Bochum, Germany \\
\hline Prof. Dr. & Carl-Christian & Freidank & University of Hamburg, Germany \\
\hline PD Dr. & Andrea & Fried & TU Chemnitz, Germany \\
\hline Prof. Dr. & Torsten J. & Gerpott & Mercator School of Management, Germany \\
\hline Prof. Dr. & Roland & Gleich & $\begin{array}{l}\text { European Business School University, } \\
\text { Germany }\end{array}$ \\
\hline Prof. Dr. & Uwe & Götze & TU Chemnitz, Germany \\
\hline Prof. Dr. & Michael & Grüning & TU Ilmenau, Germany \\
\hline Prof. Dr. & Thomas & Günther & TU Dresden, Germany \\
\hline Prof. Dr. & Roland & Helm & University Regensburg, Germany \\
\hline Dr. & Martin & Hiebl & Johannes Kepler University Linz, Austria \\
\hline Prof. Dr. & Michael & Hinz & TU Chemnitz, Germany \\
\hline Prof. Dr. & Michael & Höck & TU Freiberg, Germany \\
\hline Dr. & Martin & Holzhacker & $\begin{array}{l}\text { Erasmus University Rotterdam, The } \\
\text { Netherlands }\end{array}$ \\
\hline Prof. Dr. Dr. h.c. & Péter & Horváth & University of Stuttgart, Germany \\
\hline Prof. Dr. & Jochen & Hundsdoerfer & FU Berlin, Germany \\
\hline Prof. Dr. & Achim & Koberstein & Goethe University Frankfurt, Germany \\
\hline JProf. Dr. & Maik & Lachmann & TU Dortmund, Germany \\
\hline Prof. Dr. & Peter & Letmathe & RWTH Aachen University, Germany \\
\hline Dr. & Stefan & Linder & ESSEC Business School, Paris, France \\
\hline Prof. Dr. & Peter & Lorson & The University of Rostock, Germany \\
\hline Prof. & Paola Maria & Madini & $\begin{array}{l}\text { ESADE Ramon Llull University, Barcelona, } \\
\text { Spain }\end{array}$ \\
\hline
\end{tabular}




\begin{tabular}{|c|c|c|c|}
\hline Prof. Dr. & Matthias & Mahlendorf & $\begin{array}{l}\text { Frankfurt School of Finance and } \\
\text { Management, Germany }\end{array}$ \\
\hline Prof. & Riccardo & Manzini & Bologna University, Italy \\
\hline Prof. Dr. & Klaus & Möller & University of St. Gallen, Switzerland \\
\hline Prof. & Cristina & Mora & University of Pennsylvania, USA \\
\hline Prof. Dr. & Stefan & Müller & Helmut Schmidt University, Germany \\
\hline JProf. Dr. & Christian & Ott & European University Viadrina, Germany \\
\hline JProf. Dr. & Marko & Reimer & $\begin{array}{l}\text { WHU - Otto Beisheim School of } \\
\text { Management, Germany }\end{array}$ \\
\hline Prof. Dr. & Christian & Ringle & TU Hamburg-Harburg, Germany \\
\hline Prof. & Matteo Mario & Savino & University of Sannio, Italy \\
\hline Prof. Dr. & Utz & Schaeffer & $\begin{array}{l}\text { WHU - Otto Beisheim School of } \\
\text { Management, Germany }\end{array}$ \\
\hline JProf. Dr. & Frank & Schiemann & Universität Hamburg, Germany \\
\hline Prof. Dr. Dr. & Georg & Schneider & University of Paderborn, Germany \\
\hline Prof. Dr. & Jens Robert & Schöndube & Leibniz Universität Hannover, Germany \\
\hline Prof. Dr. & Dirk & Simons & University of Mannheim, Germany \\
\hline Prof. Dr. & Gerhard & Speckbacher & $\begin{array}{l}\text { Vienna University of Economics and } \\
\text { Business, Austria }\end{array}$ \\
\hline Dr. & Erik & Strauss & $\begin{array}{l}\text { WHU - Otto Beisheim School of } \\
\text { Management, Germany }\end{array}$ \\
\hline Prof. Dr. & Patrick & Velte & University of Lüneburg, Germany \\
\hline Prof. Dr. & Friederike & Wall & Alpen-Adria-Universität Klagenfurt, Austria \\
\hline Dr. & Gabriel & Weber & Northumbria University, UK \\
\hline Prof. Dr. & Barbara & Weissenberger & Justus Liebig University Giessen, Germany \\
\hline Prof. & Sally K. & Widener & Clemson University, USA \\
\hline Prof. Dr. & Andreas & Wömpener & University Duisburg Essen, Germany \\
\hline Prof. Dr. & Inge & Wulf & TU Clausthal, Germany \\
\hline Prof. Dr. & Torsten & Wulf & Philipps-Universität Marburg, Germany \\
\hline Prof. Dr. & Sonja & Wüstemann & European University Viadrina, Germany \\
\hline
\end{tabular}

JoMaC is very proud and happy to have such a broad fund of highly respected reviewers which helps us to further develop the submissions to the Journal of Management Control.

For the forthcoming years 2015 and 2016 special issues on interesting topics are in the pipeline. JoMaC kindly invites researchers to hand in contributions concerning the topics of the special issues and welcomes submissions:

Simulation and Management Control, guest-edited by Frederike Wall, AlpenAdria-University Klagenfurt, Austria; Paolo Pellizzari, Universitá C'a Foscari, Venezia, Italy; Deadline 31.10.2014.

Risk Management and Business Valuation in M\&A Transactions, guest-edited by Thorsten Knauer, Bayreuth University, Germany; Frank Li, Ivey University, Canada; Friedrich Sommer and Arnt Wöhrmann, University of Münster, Germany; Deadline 31.01.2015. 
Middle Managers in the Strategy Process, guest-edited by Marko Reimer, WHU Otto-Beisheim School of Management, Vallendar, Germany; Mariano L.M. Heyden, University of Newcastle, Australia; Sebastiaan van Doorn, Warwick University, UK; Deadline 28.02.2015.

This issue of the Journal of Management Control reflects well the globalization of research in management control. The authors come from three continents covering North America, Europe and Asia. Furthermore, the papers represent also three different approaches in management control research, which demonstrates the diversity in methodology in our research area.

In this issue of the Journal of Management Control Anders Nilsson, Adam S. Maiga and Fred A. Jacobs address in their paper the long-standing question of how budgetary participation affects budgetary outcomes. Information technology for enhanced communication and activity-based costing are taken into consideration as potential moderators.

Using a game-theoretic approach, the paper of Christian Lohmann and Sandro Lombardo introduces a new success indicator that establishes truthful reporting as the dominant strategy and prevents collusion or contractual agreements among divisional managers.

Finally, Akira Nishimura investigates the process by which cost design becomes environmentally conscious cost design in Japan and considers the possibility of its further development and generalization.

Dresden, August 2014

Prof. Dr. Thomas Günther

Managing editor 